\title{
Empirical Bayes Credibility Models for Economic Catastrophic Losses by Regions
}

\author{
Pavla Jindrová ${ }^{1, *}$ and Lucie Kopecká ${ }^{1}$ \\ ${ }^{1}$ University of Pardubice, Faculty of Economics and Administration, Institute of Mathematics and Quantitative Methods, Studentská 95 , \\ 53210 Pardubice, Czech Republic
}

\begin{abstract}
Catastrophic events affect various regions of the world with increasing frequency and intensity. The number of catastrophic events and the amount of economic losses is varying in different world regions. Part of these losses is covered by insurance. Catastrophe events in last years are associated with increases in premiums for some lines of business. The article focus on estimating the amount of net premiums that would be needed to cover the total or insured catastrophic losses in different world regions using Bühlmann and Bühlmann-Straub empirical credibility models based on data from Sigma Swiss Re 2010-2016. The empirical credibility models have been developed to estimate insurance premiums for short term insurance contracts using two ingredients: past data from the risk itself and collateral data from other sources considered to be relevant. In this article we deal with application of these models based on the real data about number of catastrophic events and about the total economic and insured catastrophe losses in seven regions of the world in time period 2009-2015. Estimated credible premiums by world regions provide information how much money in the monitored regions will be need to cover total and insured catastrophic losses in next year.
\end{abstract}

\section{Introduction}

Based on Sigma Swiss Re terminology [19] the term natural catastrophe refers to an event caused by natural forces.

Table 1. The Sigma event selection criteria 2015

\begin{tabular}{|cc|}
\hline \multicolumn{2}{|l|}{ Insured losses: } \\
\hline Maritime disasters & 19.7 USD million \\
\hline Aviation & 39.3 USD million \\
\hline Other losses & 48.8 USD million \\
\hline or Total economic losses: & 97.7 USD million \\
\hline or Casualties: \\
\hline Dead or missing & 20 \\
\hline Injured & 50 \\
\hline Homeless & 2000 \\
\hline Source: Sigma Swiss Re, No 1/2016, [19]
\end{tabular}

\footnotetext{
Corresponding author: Pavla.Jindrova@upce.cz
}

Such an event generally results in a large number of individual losses involving many insurance policies. An event is classified as a catastrophe and included in the Sigma database when insured claims, total losses or the number of casualties exceed certain thresholds, detailed in Table 1.

The occurrences of catastrophic events are becoming more frequent (Fig. 1) and also grow indemnity of insurance and reinsurance companies at these events (Fig. 2).

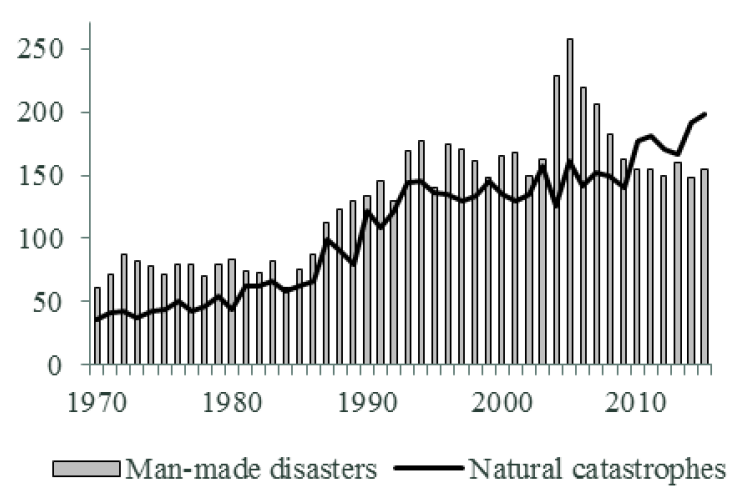

Source: Sigma Swiss Re, No 1/2016, [19] Fig. 1. Number of catastrophes events 1970-2015

By Sigma [19] there were 198 natural catastrophes in 2015, and 155 man-made disaster events. The estimated total economic losses from natural catastrophes and 
man-made disasters across the world were USD 92 billion in 2015. This is less than the USD 113 billion total loss in 2014, and is well below the inflationadjusted average of the previous 10 years (USD 192 billion).

The insurance industry covered almost USD 37 billion - less than half - of the total losses from natural and man-made disasters in 2015, and well below the inflationadjusted previous 10-year annual average of USD 62 billion. Natural catastrophes resulted in claims of USD 28 billion, the lowest since 2009 and again much lower than the previous 10-year inflation-adjusted annual average (USD 55 billion). Large man-made disasters led to claims of USD 9 billion, up from USD 7 billion in 2014.

Fig. 2 shows also the difference between insured and total losses over time period 1970-2015, termed the insurance protection or funding gap. It is the amount of financial loss generated by catastrophes not covered by insurance. In this figure it is evident growing trend both total and insured catastrophe losses in time period 19702015 , determined by 10 -years moving averages. The rate of growth of total losses has outpaced the growth of insured losses.

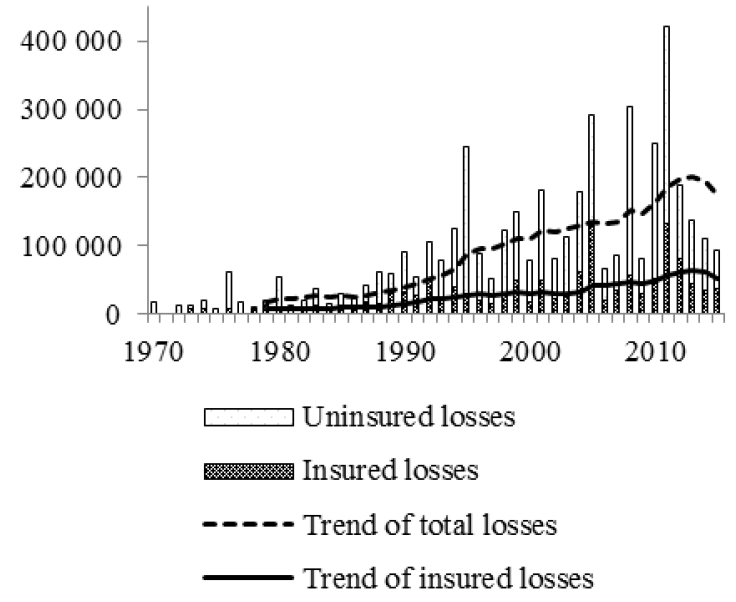

Source: Sigma Swiss Re, No 1/2016 Fig. 2. Insured and uninsured losses in 1970-2015 in USD million in 2015 prices

Catastrophic events affect various regions of the world with increasing frequency and intensity. Large catastrophic events can be caused by natural phenomena or are caused by man.

The number of catastrophic events is also varying in different regions of the world. The catastrophic events by Sigma Swiss Re are monitored for seven regions North America, Latin America, Europe, Africa, Asia, Oceania/Australia and Seas/space. Number of catastrophe events by regions in 2009-2015 present Fig. 3 and Table 2.

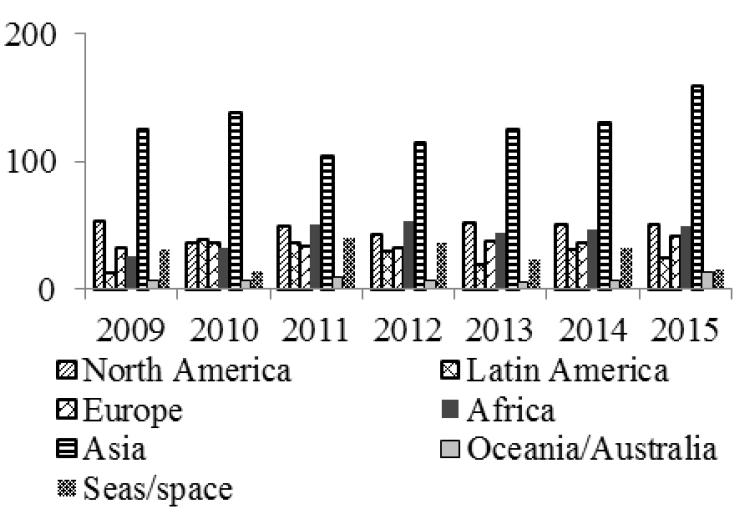

Source: Own processing by Sigma Swiss Re, 2010-2016

Fig. 3. Number of catastrophe events by regions for 2009-2015

The worldwide insurance industry has been rocked by the increasing catastrophes in recent years and increased demand for catastrophe cover (e.g., per occurrence excess of loss reinsurance), leading to a capacity shortage in catastrophe reinsurance. Catastrophe events in last years are associated with increases in premiums for some lines of business.

Table 2. Number of catastrophe events by regions (2009-2015)

\begin{tabular}{|c|c|c|c|c|c|c|c|}
\hline & $\mathbf{2 0 0 9}$ & $\mathbf{2 0 1 0}$ & $\mathbf{2 0 1 1}$ & $\mathbf{2 0 1 2}$ & $\mathbf{2 0 1 3}$ & $\mathbf{2 0 1 4}$ & $\mathbf{2 0 1 5}$ \\
\hline $\begin{array}{c}\text { North } \\
\text { America }\end{array}$ & 54 & 36 & 50 & 43 & 52 & 51 & 51 \\
\hline $\begin{array}{c}\text { Latin } \\
\text { America }\end{array}$ & 13 & 39 & 36 & 30 & 20 & 31 & 25 \\
\hline Europe & 32 & 37 & 34 & 33 & 38 & 37 & 41 \\
\hline Africa & 26 & 32 & 51 & 53 & 44 & 47 & 49 \\
\hline Asia & 125 & 139 & 104 & 115 & 125 & 130 & 159 \\
\hline $\begin{array}{c}\text { Oceania/ } \\
\text { Australia }\end{array}$ & 7 & 7 & 10 & 7 & 6 & 7 & 13 \\
\hline $\begin{array}{c}\text { Seas / } \\
\text { space }\end{array}$ & 31 & 14 & 40 & 37 & 23 & 33 & 15 \\
\hline
\end{tabular}

Source: Own processing by Sigma Swiss Re, 2010-2016

Regional differences can be observed not only in the number of catastrophic events, but also in the amount of economic losses. Part of these losses is covered by insurance. The share of insured losses on total losses again varies by region (see Table 3 and Table 4). 
Table 3. Total economic losses by region in 2009-2015 in USD billion.

\begin{tabular}{|c|c|c|c|c|c|c|c|}
\hline & $\mathbf{2 0 0 9}$ & $\mathbf{2 0 1 0}$ & $\mathbf{2 0 1 1}$ & $\mathbf{2 0 1 2}$ & $\mathbf{2 0 1 3}$ & $\mathbf{2 0 1 4}$ & $\mathbf{2 0 1 5}$ \\
\hline $\begin{array}{c}\text { North } \\
\text { America }\end{array}$ & 20.1 & 20.6 & 63.5 & 118.5 & 32.0 & 28.6 & 28.6 \\
\hline $\begin{array}{c}\text { Latin } \\
\text { America }\end{array}$ & 0.6 & 53.4 & 5.6 & 4.2 & 9.0 & 8.2 & 7.5 \\
\hline Europe & 20.1 & 35.2 & 8.7 & 26.8 & 33.0 & 15.9 & 12.6 \\
\hline Africa & 0.5 & 0.3 & 1.6 & 1.5 & 1.0 & 1.5 & 1.2 \\
\hline Asia & 16.7 & 78.8 & 260.1 & 30.5 & 62.0 & 51.7 & 37.7 \\
\hline $\begin{array}{c}\text { Oceania/ } \\
\text { Australia }\end{array}$ & 2.1 & 13.1 & 27.8 & 1.1 & 3.0 & 2.3 & 3.0 \\
\hline $\begin{array}{c}\text { Seas / } \\
\text { space }\end{array}$ & 2.0 & 20.6 & 3.6 & 3.1 & 1.0 & 1.7 & 1.1 \\
\hline
\end{tabular}

Source: Own processing by Sigma Swiss Re, 2010-2016

The collected premiums used to cover the insured losses not only in the region of insured, but if necessary, in other regions of the world. It is caused by the globalization of the insurance and reinsurance market.

Table 4. Insurance losses by region in 2009-2015 in USD billion.

\begin{tabular}{|c|c|c|c|c|c|c|c|}
\hline & 2009 & 2010 & 2011 & 2012 & 2013 & 2014 & 2015 \\
\hline $\begin{array}{c}\text { North } \\
\text { America }\end{array}$ & 12.7 & 15.3 & 39.8 & 64.6 & 19.0 & 17.5 & 17.3 \\
\hline $\begin{array}{c}\text { Latin } \\
\text { America }\end{array}$ & 0.1 & 9.0 & 0.6 & 0.9 & 2.0 & 2.3 & 3.2 \\
\hline Europe & 7.7 & 6.3 & 4.3 & 5.5 & 15.0 & 6.6 & 6.2 \\
\hline Africa & 0.2 & 0.1 & 0.3 & 0.2 & 1.0 & 0.8 & 0.0 \\
\hline Asia & 2.4 & 2.2 & 49.2 & 3.4 & 6.0 & 5.2 & 7.0 \\
\hline $\begin{array}{l}\text { Oceania/ } \\
\text { Australia }\end{array}$ & 1.3 & 8.9 & 19.1 & 0.3 & 1.0 & 1.0 & 2.1 \\
\hline $\begin{array}{l}\text { Seas / } \\
\text { space }\end{array}$ & 2.0 & 1.6 & 2.4 & 2.4 & 1.0 & 1.3 & 0.9 \\
\hline
\end{tabular}

The article will therefore focus on estimating the amount of net premiums that would be needed to cover the total catastrophic losses in each region. For this purpose we will use empirical credibility models.

\section{Application of Bühlmann credibility model}

Credibility theory is a technique, or set of techniques, for calculating premiums for short term insurance contracts. The technique calculates a premium for a risk (in our case for a region) using two ingredients: past data from the risk itself and collateral data, i.e. data from other sources considered to be relevant, in our cases from other regions. The essential features of a credibility premium are that it is a linear function of the past data from the risk itself and that it allows for the premium to be regularly updated as more data are collected in the future $[1,2,12,13,15,18]$.

A credibility premium represents a compromise between the two above mentioned sources of information. The credibility formula for estimation of pure premium $P_{c}$ in next year is $[6,7]$ :

$$
P_{c}=Z P_{r}+(1-Z) \mu
$$

where $P_{r}$ is estimation based on own past data in risk, or region, $\mu$ is estimation based on collateral data and $Z$ is a number between zero and one, known as the credibility factor. Credibility factor $Z$ is a measure of how much reliance the company is prepared to place on the own data $[8,9,10]$.

Empirical Bayes credibility theory is the collective name for the vast literature which has developed since Bühlmann [2] and Bühlmann and Straub [3].

The form of empirical Bayes credibility premium as a result of Bühlmann credibility model has been derived in [2] as

$$
E(m(\theta) / \boldsymbol{x})=Z \bar{x}+(1-Z) E(m(\theta))
$$

with factor credibility

$$
Z=\frac{n}{n+\frac{E\left(s^{2}(\theta)\right)}{D(m(\theta))}}
$$

In empirical Bayes credibility model we use the available data (Tab. 3) to estimate the quantities $E(m(\theta)), D(m(\theta)), E\left(s^{2}(\theta)\right)$, and hence obtain a Bühlman type credibility premium estimate [2] for a particular risk.

Derived relations necessary for estimates are:

$$
\begin{aligned}
\operatorname{est} E(m(\theta))= & \bar{X} \\
\operatorname{est} E\left(s^{2}(\theta)\right)= & \frac{1}{N} \sum_{i=1}^{N} \frac{1}{n-1} \sum_{j=1}^{n}\left(X_{i j}-\bar{X}_{i}\right)^{2} \\
\operatorname{est} D(m(\theta))= & \frac{1}{N-1} \sum_{i=1}^{N}\left(\bar{X}_{i}-\bar{X}\right)^{2}- \\
& -\frac{1}{N n} \sum_{i=1}^{N} \frac{1}{n-1} \sum_{j=1}^{n}\left(X_{i j}-\bar{X}_{i}\right)^{2}
\end{aligned}
$$

The derivation of these relations can be found in Bühlmann [2] and Waters [18].

Table 3 and Fig. 4 give present the total economic losses (in USD billion) to each of seven regions of the world over seven years. 


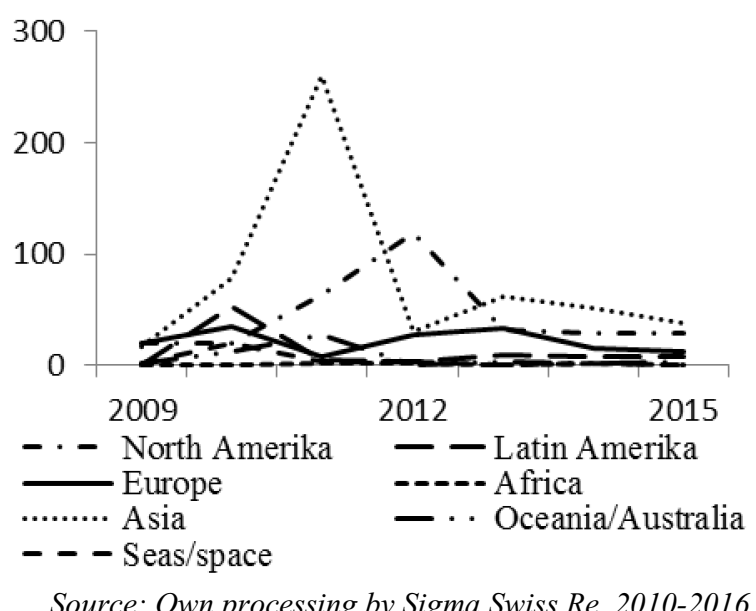

Fig. 4. Times series plot of total economic losses in USD bn

Using the Bühlmann credibility model we have calculated the credibility factor and credibility premium for next year for each of the seven regions. For each of the regions we calculate means $\bar{X}_{i}=\sum_{j=1}^{n} X_{i j} / n$. These values contains second column in Table 5 .

Table 5. Results of Bühlmann credibility model.

\begin{tabular}{|c|c|c|}
\hline & $\overline{X_{i}}$ & $\begin{array}{c}\text { Credibility } \\
\text { premium }\end{array}$ \\
\hline $\begin{array}{c}\text { North } \\
\text { America }\end{array}$ & 44.54 & 39.66 \\
\hline $\begin{array}{c}\text { Latin } \\
\text { America }\end{array}$ & 12.63 & 15.38 \\
\hline Europe & 21.76 & 22.33 \\
\hline Africa & 1.08 & 6.60 \\
\hline Asia & 76.80 & 64.21 \\
\hline $\begin{array}{c}\text { Oceania / } \\
\text { Australia }\end{array}$ & 7.48 & 11.47 \\
\hline Seas/space & 4.73 & 9.38 \\
\hline
\end{tabular}

Source: Own calculations

Using expressions (4) - (6) we have estimated $E(m(\theta)), E\left(s^{2}(\theta)\right), \quad D(m(\theta))$ :

$$
\begin{aligned}
& \operatorname{est} E(m(\theta))=24.1481 ; \\
& \operatorname{estE}\left(s^{2}(\theta)\right)=1259.777 \\
& \operatorname{estD}(m(\theta))=572.2954
\end{aligned}
$$

Therefore using (3) we have calculated the credibility factor $Z$ which is the same for each region:

$$
Z=0,7608
$$

The credibility premium for each of seven regions in USD billion by (2) is in last column of Table 5 .

\section{Application of Bühlmann - Straub credibility model}

Contrary to the Bühlmann model in section 3 BühlmannStraub credibility model accounts for the varying annual volume of business, as is for example observed number of claims. We have applied this model on insured catastrophe losses (Table 4) and figure 5 with acceptation of the number of catastrophe events (Table 2).

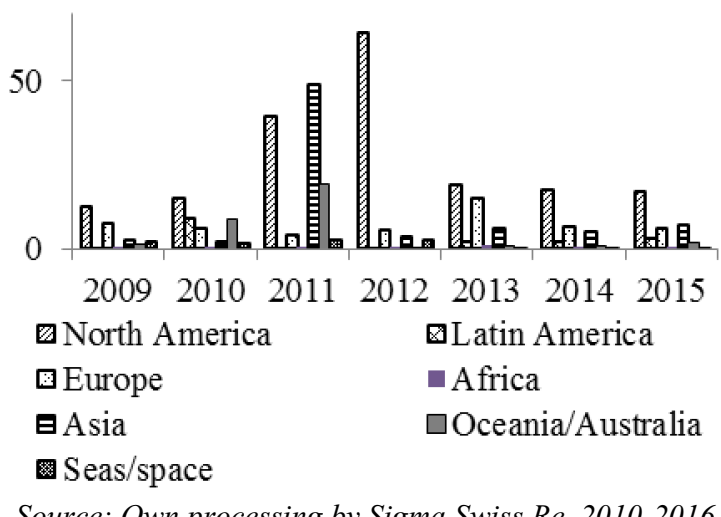

Source: Own processing by Sigma Swiss Re, 2010-2016 Fig. 5. Insured catastrophe losses by regions in 2009-2015 in USD billion

Let region, for which the estimates of insurance catastrophic loses are computed, is one of $N$ regions. Insured losses in previous $n$ years are known for all these regions.

Let $P_{i \mathrm{j}}$ is a variable, describing number of catastrophic events of the $i$-th observed region $(i=1, \ldots$, $N ; N=7)$ in the $j$-th year $(\mathrm{j}=1, \ldots, n ; n=7)$.

Let $Y_{i j}$ is the size of insured catastrophe losses for each region $i=1, \ldots, N$ and each year $j=1, \ldots, n$.

According to $[4,5,11,13,16,17,18]$ for the estimation of credible net insured premium for the $i$-th risk, the following formula is used

$$
\begin{aligned}
E(m(\theta) / X) & =Z_{i} \bar{X}_{i}+\left(1-Z_{i}\right) E(m(\theta)) \\
& =Z_{i} \bar{X}_{i}+\left(1-Z_{i}\right) \bar{X}
\end{aligned}
$$

Credibility factor for the $i$-th risk is calculated in form $[3,18]$ :

$$
Z_{i}=\frac{P_{i}}{P_{i}+\frac{E\left(s^{2}(\theta)\right)}{D(m(\theta))}}
$$

The rules for estimating the parameters $E(m(\theta)), E\left(s^{2}(\theta)\right), D(m(\theta))$ are by $[3,18]$ :

$$
\begin{gathered}
\operatorname{est}(m(\theta))=\bar{X} \\
\operatorname{estE}\left(s^{2}(\theta)\right)=\frac{1}{N(n-1)} \sum_{i=1}^{N} \sum_{j=1}^{n} P_{i j}\left(X_{i j}-\bar{X}_{i}\right)^{2}
\end{gathered}
$$




$$
\operatorname{est} D(m(\theta))=\frac{1}{P^{*}}\left\{\begin{array}{l}
\frac{1}{N n-1} \sum_{i=1}^{N} \sum_{j=1}^{n} P_{i j}\left(X_{i j}-\bar{X}\right)^{2} \\
-\frac{1}{N(n-1)} \sum_{i=1}^{N} \sum_{j=1}^{n} P_{i j}\left(X_{i j}-\bar{X}_{i}\right)^{2}
\end{array}\right\}
$$

when it is mean, that

$$
\begin{gathered}
\bar{X}_{i}=\frac{1}{P_{i}} \sum_{j=1}^{n} P_{i j} X_{i j}=\frac{1}{P_{i}} \sum_{i=1}^{n} Y_{i j} \\
\bar{X}=\frac{1}{P} \sum_{i=1}^{N} \sum_{j=1}^{n} P_{i j} X_{i j}=\frac{1}{P} \sum_{i=1}^{N} P_{i} \bar{X}_{i} \\
P^{*}=\frac{1}{N n-1} \sum_{i=1}^{N} P_{i} \cdot\left(1-\frac{P_{i}}{P}\right)
\end{gathered}
$$

The value of credibility factor shows the rate of reliability of own data for each region.

The estimates of parameters $E(m(\theta)), \quad D(m(\theta))$, $E\left(s^{2}(\theta)\right)$ are the same for all the regions. Credibility factor $Z_{i}$ differs for each region. The higher is the value of risk rate $P_{i}$, the higher is the value of credibility factor $Z_{i}$.

Bühlmann-Straub model was applied to compute credible net premium for seven regions of the world based insured catastrophe losses in time period 20092015 published in Sigma Swiss Re [20] (Table 4).

Total amount of insured losses $Y_{i}$, where $Y_{i}=\sum_{j=1}^{n} Y_{i j}$, insured by each region $i$ in the time 2009-2015, total number of catastrophic events $P_{i}$, where $P_{i}=\sum_{j=1}^{n} P_{i j}$ by each region in the whole period, and average insured catastrophe losses per insurance events $\bar{X}_{i}$ for each region were computed according to (12). These characteristics present Table 6 .

Table 6. Computed characteristics of the regions

\begin{tabular}{|c|c|c|c|}
\hline & $\boldsymbol{P}_{\boldsymbol{i}}$ & $\boldsymbol{Y}_{\boldsymbol{i}}$ & $\overline{X_{i}}$ \\
\hline $\begin{array}{c}\text { North } \\
\text { America }\end{array}$ & 337 & 186.16 & 0.5524 \\
\hline $\begin{array}{c}\text { Latin } \\
\text { America }\end{array}$ & 194 & 18.06 & 0.0931 \\
\hline Europe & 252 & 51.64 & 0.2049 \\
\hline Africa & 302 & 2.67 & 0.0088 \\
\hline Asia & 897 & 75.53 & 0.0842 \\
\hline $\begin{array}{c}\text { Oceania / } \\
\text { Australia }\end{array}$ & 57 & 33.66 & 0.5906 \\
\hline Seas/space & 193 & 11.59 & 0.0600 \\
\hline
\end{tabular}

Source: Own calculations
Computed values in Table 6 have used to estimate parameters of the Bühlmann-Straub credibility model according to (9)-(11):

$$
\begin{aligned}
\operatorname{est} E(m(\theta)) & =0.1699 \\
\operatorname{est} E\left(s^{2}(\theta)\right) & =2.4757 \\
\operatorname{est} D(m(\theta)) & =0.0366 .
\end{aligned}
$$

According to (8), values of credibility factors $Z_{i}$ are computed for each region. It is necessary to find these values to be able to estimate credible net premium per region according to (7). Values of credibility factors and values of credible net premiums by regions contain Table 7 .

Table 7. Credibility factor $Z_{i}$ and estimates of net insurance premium per region in 2016.

\begin{tabular}{|c|c|c|}
\hline & $\boldsymbol{Z}_{\boldsymbol{i}}$ & $\begin{array}{c}\text { Net } \\
\text { insurance } \\
\text { premium }\end{array}$ \\
\hline $\begin{array}{c}\text { North } \\
\text { America }\end{array}$ & 0.8327 & 0.4884 \\
\hline $\begin{array}{c}\text { Latin } \\
\text { America }\end{array}$ & 0.7413 & 0.1130 \\
\hline Europe & 0.7882 & 0.1975 \\
\hline Africa & 0.8168 & 0.0383 \\
\hline Asia & 0.9298 & 0.0902 \\
\hline $\begin{array}{c}\text { Oceania / } \\
\text { Australia }\end{array}$ & 0.4570 & 0.3622 \\
\hline Seas/space & 0.7403 & 0.0886 \\
\hline
\end{tabular}

Source: Own calculations

Estimates of credible net premiums by regions provide information how much money in the region will be needed to cover insured catastrophe losses in next year.

\section{Conclusion}

The enormous impact of catastrophic events on our society is deep and long. Not only we need to investigate the causes of such events and develop plans to protect against them, but also we will have to resolve the resulting huge financial losses.

Results of application Bühlmann credibility empirical model in Table 5 provide an estimate of the total amount of credible premium in the regions of the world in the sum of USD 169,03 billion in year 2016, the highest in Asia and North America.

Development of the financial consequences of natural and man-made catastrophes have a major impact on the global insurance market and forcing the insurance 
and reinsurance companies to seek for new approaches and ways to cover these risks [14].

Raises the concern that the capacity of the world's insurance and reinsurance markets in the future will not be sufficient to cover these risks and aims to seek alternative options for their transfer.

\section{Acknowledgement}

This paper was supported by SGS University of Pardubice, FEA, No. SGS_2016_023, "Ekonomický a sociální rozvoj v soukromém a veřejném sektoru".

\section{References}

1. P. J. Boland, Statistical and Probabilistic Methods in Actuarial Science. (New York: Taylor \& Francis Group, 2007)

2. H. Bühlmann, Experience rating and credibility. ASTIN Bull. 4, pp. 199-207 (1967)

3. H. Bühlmann, E. Straub, Glaubwürdigkeit für Schadensätze. Mitteilungen der Vereinigung Schweizerischer Versicherungs-mathematiker 70, pp. 111-133 (1970)

4. J. Gogola, Method for permanent adjustments of premium in non-life insurance (Spôsob permanentnej úpravy výšky pojistného v neživotnom poistení). $E+M$ Economics and Management, 16 (4), pp.134-141 (2013)

5. P. Jindrová, Credibility Risk Models in Accident Insurance. In Proceedings of the 7th International Scientific Conference: Managing and Modelling of Financial risk, pp. 307-316. (2014)

6. P. Jindrová, V. Pacáková, Bayesian Probability Models for Critical Illness Insurance. In Recent Advances in Mathematical Methods in Applied Sciences. Athens, pp. 218-221 (2014)

7. P. Jindrová, V. Pacáková, Actuarial Models for Valuation of Critical Illness Insurance. International Journal of Mathematical Models and Methods in Applied Sciences, 9, pp. 218-222 (2015)

8. P. Jindrová, K. Seinerová, Bayesian Estimates of the Regional Costs in Public Health System of the Czech Republic. In Proceedings of the 12th International Scientific Conference: European Financial Systems 2015, pp. 246-252 (2015)

9. P. Jindrová, K. Seinerová, Bayesian Estimates of Health Care Costs in Slovakian Insurance Companies. International Journal of Economics and Statistics, 3, pp. 174-177 (2015)

10. P. Jindrová, K. Seinerová, Comparison of Bayesian Estimates of Health Care Costs for Czech and Slovakian Insurance Companies, Scientific Papers of the University of Pardubice, Series D, 37 (2/2016), pp. 48-59 (2016)

11. B. Linda, J. Kubanová, Credibility Premium Calculation in Motor Third-Party Liability Insurance, WSEAS conference Advances in Mathematical and Computational Methods, Malta, pp. 259-263 (2012)

12. V. Pacáková, Bayesian Estimations in Insurance Theory and Practice. In Advances in Mathematical and Computational Methods: proceedings of the 14th International Conference on Mathematical and Computational methods in Science and Engeneering, pp. 127-131 (2012)

13. V. Pacáková, Credibility models for permanently updated estimates in insurance. International journal of mathematical models and methods in applied sciences, 3(7), pp. 333-340 (2013)

14. V. Pacáková, P. Jindrová, Simulation of the highest insured catastrophe losses using quantile function. International Journal of Mathematics and Computers in Simulation. NAUN, 10, pp. 242-248 (2016)

15. V. Pacáková, B. Linda, Simulation of the extreme losses in non-life insurance $E \& M$ EKONOMIE $A$ MANAGEMENT, 12(4), pp. 97-103 (2009)

16. V. Pacáková, E. Šoltés, T. Šoltésová, Credibility Estimation of the Claim frequency. $E \& M$ EKONOMIE A MANAGEMENT, 12(2), pp. 122-126 (2009)

17. E. Šoltés, V. Pacáková, T. Šoltésová, Selected credibility regression models in motor hull insurance (Vybrané kredibilné regresné modely v havarijnom poistení), Ekonomicky casopis, 54(2), pp. 168-182 (2006)

18. H. R. Waters, Credibility Theory (Edinburgh: Heriot-Watt University, 1993)

19. Natural catastrophes and man-made disasters in 2015: Asia suffers substantial losses. Sigma No 1/2016, Swiss Re Ltd, Economic Research \& Consulting, Zurich (2016) [online] Available from: http://reliefweb.int/sites/reliefweb.int/files/resources /sigma1_2016_en.pdf

20. Sigma Swiss Re 2010-2016 [online] Available from: http://www.swissre.com/sigma/ 